\title{
THE CONCEPT OF ENTERPRISE SECURITY MANAGEMENT
}

\section{Demenska K. S.}

\section{INTRODUCTION}

The security of the enterprise (firm) should be understood as the state of its stable activity, in which programs are implemented, profit and protection against external and internal destabilizing factors are provided.

The main aspects of the concept "security":

- external and internal threats;

- existence of vital interests of the objects of protection;

- balance of interests between them.

The presence of threats is primary in these definitions. And this is natural, because if they are not there, what then to defend from? The secondary aspect is the existence of vital interests, i.e. those interests, the implementation of which determines the existence of security objects and without which objects cease to exist as a whole. For example, for the state it is sovereignty and integrity of borders, economic growth; for the enterprise - effective current activity and stable tendencies of development ${ }^{1}$.

\section{Concepts and types of enterprise security}

The purpose of ensuring the security of an enterprise (firm) should be a comprehensive counteraction to potential and real threats, the elimination or minimization of which should guarantee the economic entity the success of functioning in unstable conditions of the external and internal environment.

The security of the enterprise can be divided into the following types (Fig. 1).

The central element of ensuring the enterprise security in general is the economic security of the entity.

\footnotetext{
${ }^{1}$ Користін О.С., Чернявський С.С. Протидія відмиванню коштів в Україні: правові та організаційні засади правоохоронної діяльності : навчальний посібник. Київ, 2009. 612 с.
} 


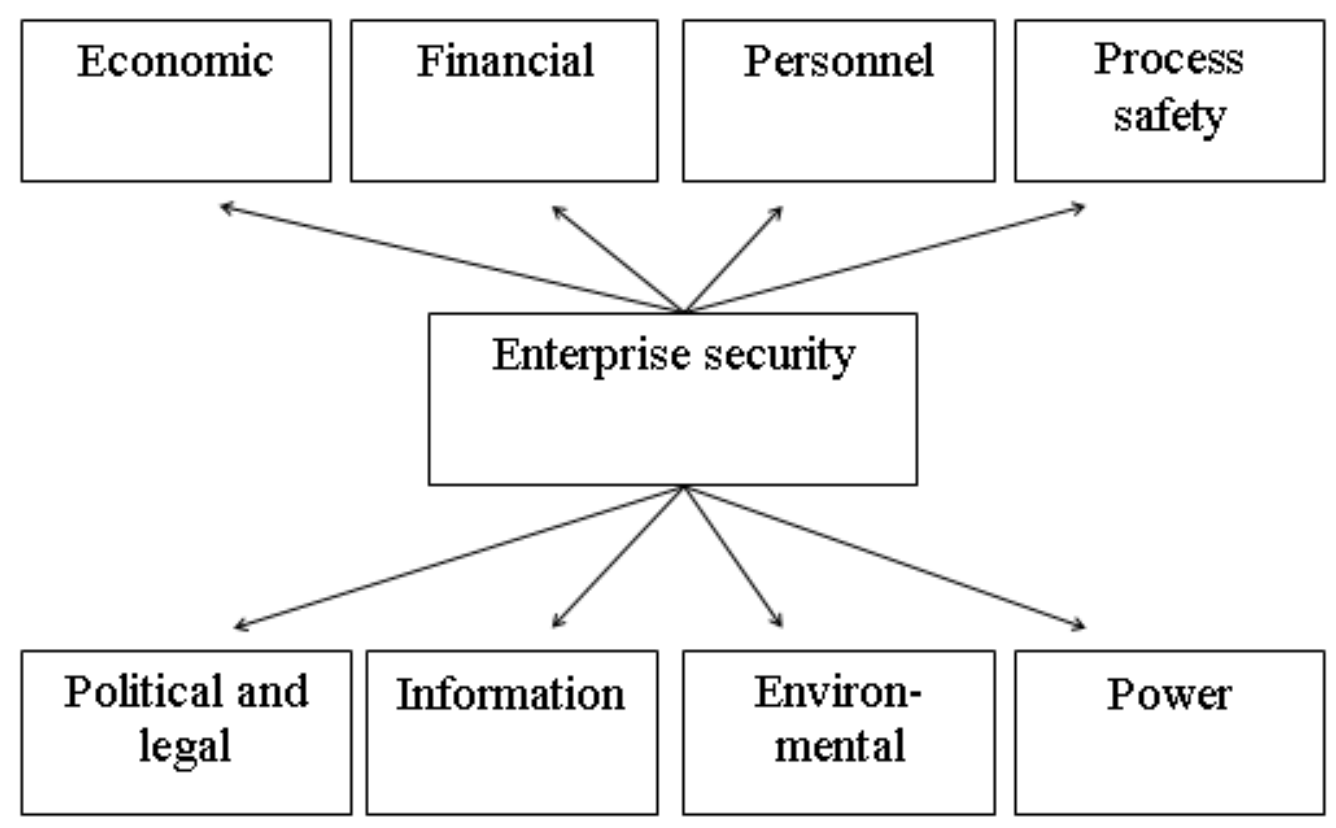

Figure 1. Types of enterprise security

The concept of economic security has undergone a lot of rethinking in economic theory due to changes in environmental conditions and taking into account the factors that determine management processes. In the modern scientific literature, the term "economic security" is often derived directly from the more general category of security (from Greek means "to control the situation"). The professional literature provides a definition of security as a condition in which any object is in a position of reliable protection and is not exposed to the negative influence of any factors. In a general scientific sense, security means the protection of naturalphysiological, socio-economic, ideal-spiritual and situational needs for resources, technologies, information and moral ideals necessary for the life and development of the population ${ }^{2}$.

Another important component of enterprise security is financial security. Without ensuring sustainable financial security, it is almost impossible to solve any of the tasks facing the enterprise.

The concept of financial security is as broad as the interpretation of finance as an economic category. Today there is no one well-established definition of "financial security". The existing wording reflects only certain aspects of financial security and cannot claim its unambiguous and

\footnotetext{
${ }^{2}$ Ігнашкіна Т.Б. Економічна безпека підприємства та їі трактування у праць. ПдТУ. Маріуполь, 2011. T. 2. C. $204-207$.
} 
full interpretation. Financial security as a definition is viewed from different angles, in particular:

- resource and functional approach determines financial security as protection of financial interests of business entities at all levels of financial relations; security of households, enterprises, organizations, institutions, regions, industries and sectors of the state's economy with financial resources sufficient to meet their needs and fulfill their obligations;

- in terms of statistic, financial security is a state of financial, monetary, currency, banking, budgetary, tax, investment, customs, tariff and stock systems characterized by balance and resistance to internal and external negative impacts, ability to prevent external financial expansion to ensure the effective functioning of the national economic system and economic growth;

- in the context of legal regulation, financial security provides the creation of such conditions for the functioning of the financial system, in which, firstly, there is no possibility to direct financial flows to the areas of their use that are not protected by legislative acts, and, secondly, the possibility of abuse of financial resources has been reduced to a minimum ${ }^{3}$.

Thus, from the standpoint of a multifaceted approach, financial security is the protection of financial interests at all levels of financial relations; a certain level of independence and stability of a country's financial system under external and internal destabilizing factors that threaten its financial security; the ability of the financial system of the state to ensure the effective functioning of the national economic system and sustainable economic growth.

One of the most important aspects of the organization of enterprise security is work with personnel. Personnel security is the process of preventing the negative impact on the enterprise security due to the risks and threats related to the personnel, its intellectual potential and labor relations in general.

Personnel security plays a dominant role in the security system of the company, as it is the work with human resources, and they are the primary in any organization.

In fact, in addition to external threats to the security of the company, there are internal, arising from its own personnel. Here we are not even talking about the economic threat that may arise due to someone's negligence,

${ }^{3}$ Фінанси : Підручник. 4-те вид. Київ : Центр учбової літератури, 2009. 312 с. 
incompetence or mere accident. We mean quite deliberate theft, sabotage, bribery, disclosure of trade secrets and other unfair actions of employees.

Therefore, an important component of enterprise security is personnel security. It is a process of preventing negative impacts on the enterprise security because of the risks and threats related to the personnel, its intellectual potential and labor relations in general ${ }^{4}$.

Enterprise process safety is the level of conformity of the technologies applied at the enterprise to the best analogues in the world for cost optimization. The negative effects on this component include:

actions aimed at undermining the technological potential of the enterprise;

violation of technological discipline;

obsolescence of the used technologies.

A lack of external and internal investment can be considered as external threats to the weakening of process safety. Difficulties in obtaining long-term loans from banks make it impossible to replenish the working capital of the enterprise and direct them to the equipment fleet.

All this leads to the use of outdated equipment, technology and a significant threat to process safety of the enterprise.

Increasing energy prices, the absence of long-term supplier contracts, supplier failure are external security threats that are quite high. Ukraine purchases more than half of the required energy resources abroad, which is why rising energy prices leads to an increase in the cost of production ${ }^{5}$.

Political and legal security of the enterprise is protection against excessive tax pressure, unstable legislation, and inefficient work of the legal department of the enterprise. It defines the environment in which businesses operate as well as the "rules of the game for them".

The legal component is the comprehensive legal support of the enterprise, compliance with current legislation. The legal danger is posed by:

insufficient legal protection of the enterprise's interests in contract and other business documents;

poor qualification of the employees of the relevant economic entity's legal service and mistakes in the recruitment of that entity;

\footnotetext{
${ }^{4}$ Швець Н.Р. Методи виявлення і збереження кадрової безпеки, або Як перемогти зловживання персоналу. Київ : Журнал «Персонал». 2006. № 5.

${ }^{5}$ Іванілов О.С. Економіка підприємства : підручник 2-ге видання Затверджено Міністерством освіти і науки України для студентів вищих навчальних закладів. Київ : «Центр учбової літератури», 2011.
} 
violation of legal rights of the enterprise and its employees;

intentional or unintentional disclosure of commercially important information;

violation of patent law.

The legal patent and licensing service should deal with counteracting these negative impacts; in particular, it should provide legal support for the activity of the enterprise, legal processing of contract documentation, conducting legal and arbitration proceedings, legal training of personnel, control of violations of patent law, etc.

External threat of political and legal enterprise security is frequent changes of the government, instability of the tax system, excessive state interference in business affairs, etc. The lack of legal guarantees in the case of forcible alienation of property, blocking of accounts of enterprises is a serious threat to the activity of the enterprise.

The purpose of the Enterprise Information Security Component is to ensure the continuous working of the organization and to minimize damage from the events containing a security threat.

Information security requires solution to the following issues:

1. Security Policy.

2. Organization of protection.

3. Classification of resources and their control.

4. Personnel security.

5. Physical and environmental security.

6. Administration of computer systems and computer networks.

7. Access control systems.

8. Development and maintenance of information systems.

9. Planning for the continuous working of the organization.

10. Compliance with requirements.

Information security: protection of information; its components:

a) protecting sensible information from unauthorized disclosure or interception;

b) ensuring the accuracy and completeness of information and computer programs;

c) ensuring the availability of information and vital services, when it is required by the user.

Information security management provides a mechanism that enables the implementation of information security. 
Risk analysis is a comprehensive term that includes:

- identifying and analyzing the potential threats to computer systems and their vulnerabilities;

- providing management with the information needed to make decisions related to the optimization of investment in information security measures.

Security incident is an event that resulted (or could have resulted) in the loss or damage of an organization's information resources, or an action that violates the organization's security rules.

It is also necessary to consider the enterprise security in the environmental sphere. Environmental enterprise security is protection against the destructive influence of natural, man-made factors and the consequences of the enterprise's business activity. Floods, earthquakes, tornadoes, landslides, avalanches can cause enormous damage to the property of the enterprise and the health of workers. It is impossible to predict natural disasters in practice, but every effort must be made to minimize the consequences of natural disasters for the enterprise. Man-made disasters arise from the use of physically worn-out fixed assets, unplanned power outages or because of the poor qualification and irresponsibility of workers. Environmental losses can significantly affect the financial condition of the company. For example, such events as a legal action for violations of environmental legislation, an accident with environmental consequences at the enterprise, cause losses that fall into the financial and environmental category and are measured in monetary form. Environmental losses due to the loss of health of the company's employees, the reduction of production volumes and sales of products affect the financial position of the company slightly slower. Environmental damage such as human suffering due to loss of health cannot be measured in monetary terms. Compensation for that is determined subjectively. The environmental damages of the company may be uncovered or partially covered. For the organization it is a significant source of danger ${ }^{6}$.

Power enterprise security is protection of an individual from threats to his life, health and material welfare, as well as protection of the enterprise's property from criminal encroachments. The power component is to ensure the physical security of the employees (especially the

\footnotetext{
${ }^{6}$ Ортинський В.Л., Керницький І.С., Живко З.Б. Економічна безпека підприємств, організацій та установ : навчальний посібник. Київ : Правова єдність, 2009. 542 с.
} 
managers) and to preserve property of the enterprise. The main negative impacts on this component include physical and moral influences on specific individuals (especially on management and leading specialists) in order to harm their health and reputation, which threatens the normal activity of their enterprise.

Negative impacts that cause damage to the property of the enterprise, threaten to reduce the value of its assets and loss of industrial independence (misinformation, destruction of information). The causes of these negative phenomena are:

the inability of competitors to achieve the benefits using correct methods of market character, that is, by improving the quality of their own products, reducing current costs of production (activity), improving market research, etc.;

criminal motives for obtaining income by criminal legal entities (individuals) through blackmail, fraud or theft;

non-commercial motives for encroachment on the life and health of managers and employees of the enterprise (organization), as well as on the property of the company.

Ensuring the safety of business entities is a relatively new phenomenon for Ukraine, but at the same time it has acquired a very serious relevance. The formation and development of domestic entrepreneurial business was influenced by various factors, mostly negative ones.

The lack of proper protection of business activities by the state, the imperfection of legal regulation of relationships in the field of business security did not create preconditions for its effective development, which in turn forced entrepreneurs to seek ways of survival, focusing on their own opportunities. During more than 20 years of existence of an independent Ukraine, the activity of domestic entrepreneurial business not only gained certain economic development and experience, but also steeled itself in the constant fight against all kinds of dangers and threats. For such a struggle, domestic entrepreneurs have created a powerful system of their own security, which has been hindered by unfair and criminal activity in the sphere of business, and protects the interests of business entities in their relations with competitors, counterparties, clients, and the state.

An analysis of recent studies and publications has shown that many works by both Ukrainian and foreign scientists are devoted to the issue of security. There are many different approaches to determining the enterprise 
security, but as a rule, they are subjective and do not cover the main issues of the topic. Therefore, for further research it is advisable to improve the concept of enterprise security, as well as to identify and motivate such an important type of security as process security.

The main purpose of security management is to ensure the efficient functioning of the economic use of all enterprise resources (capital, labor force, information, technology, equipment, rights), and sufficient skill level of personnel that gives the opportunity to use them most effectively for stable functioning and dynamic scientific, technical and social development, as well as for constant increase of the existing enterprise's potential and its stable development.

\section{Factors affecting enterprise security}

Security of the enterprise as an economic entity includes its security at all stages of the enterprise operating cycle. Therefore, security should be understood as the ability of the enterprise to resist and function normally under the influence of internal and external threats that can negatively affect its work and development. In order to maintain a stable level of security, it becomes expedient to identify these threats and determine their impact on the production process. For this purpose it is necessary to classify the main factors that can interfere with the normal functioning of the enterprise into groups and to carry out their analysis (Fig. 2).
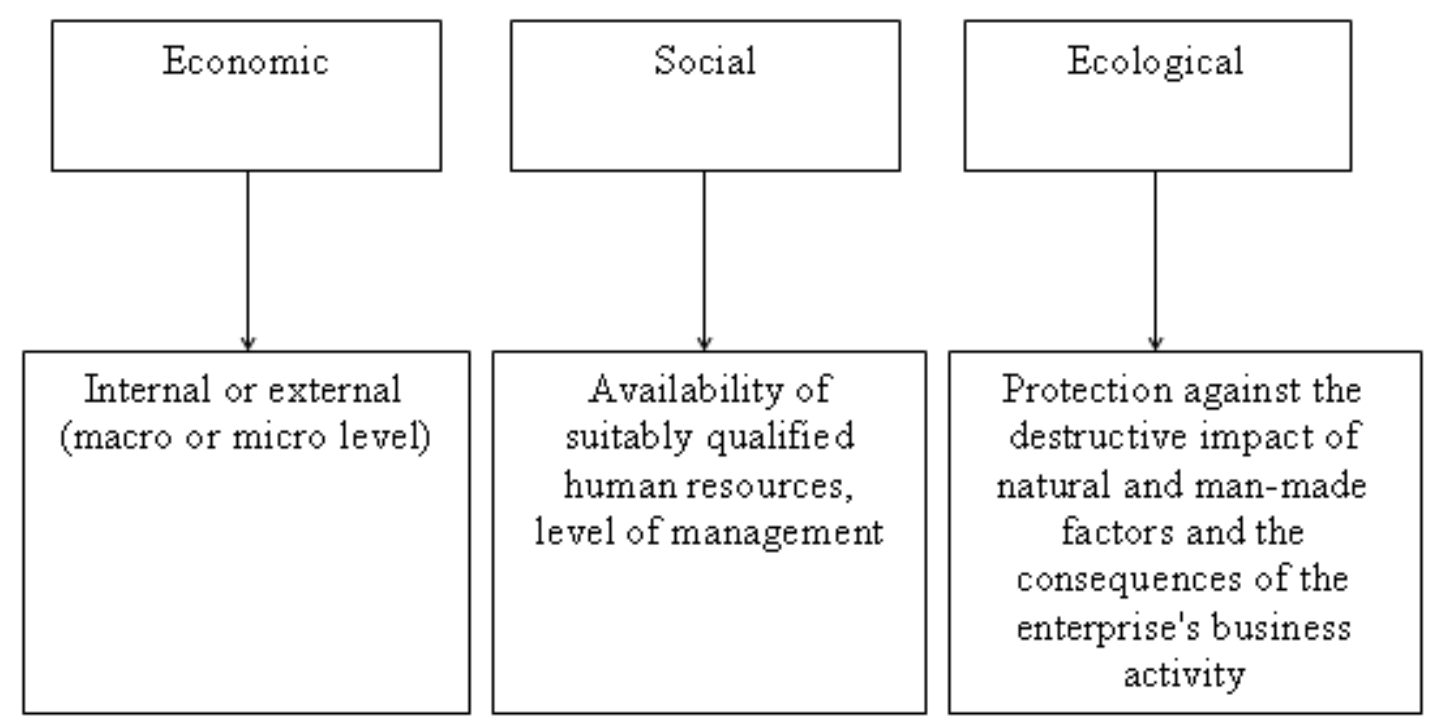

Figure 2. Classification of factors that cause production failure 
There are two types of economic factors: external and internal. External factors include:

Table 1

\section{Classification of external economic factors}

\begin{tabular}{|c|c|}
\hline External factors & Opportunities and threats \\
\hline \multirow{13}{*}{ Economic } & economic situation in the country \\
\hline & monetary policy \\
\hline & distribution of state budget funds \\
\hline & inflation rate \\
\hline & increase (or decrease) in production volumes \\
\hline & consumer activity \\
\hline & degree of consumer satisfaction \\
\hline & $\begin{array}{l}\text { the attitude of consumers to the quality of goods } \\
\text { and services }\end{array}$ \\
\hline & price level for the supplied products \\
\hline & the quality of the supplied products \\
\hline & supplier reliability \\
\hline & fairness of the competition \\
\hline & level of goods competitiveness \\
\hline \multirow{3}{*}{ Social labor } & income level of the population \\
\hline & unemployment rate \\
\hline & demographic situation \\
\hline \multirow{3}{*}{ Political } & political stability (or instability) \\
\hline & legislative and regulatory frameworks \\
\hline & the nature of recent reforms \\
\hline \multirow{2}{*}{$\begin{array}{l}\text { Scientific, technical } \\
\text { and innovative }\end{array}$} & development and introduction of new technologies \\
\hline & $\begin{array}{l}\text { state support in scientific, technical and innovative } \\
\text { sectors }\end{array}$ \\
\hline \multirow{3}{*}{ Legal } & $\begin{array}{l}\text { nature and level of implementation of legislative } \\
\text { acts }\end{array}$ \\
\hline & changes in tax legislation \\
\hline & legislative regulation of social and labor issues \\
\hline \multirow{3}{*}{$\begin{array}{l}\text { Natural and } \\
\text { geographic }\end{array}$} & availability of natural resources \\
\hline & geographical location of the enterprise \\
\hline & state of the enterprise environment \\
\hline
\end{tabular}


Internal factors include:

Table 2

Classification of internal economic factors

\begin{tabular}{|l|l|}
\hline Internal factors & \multicolumn{1}{|c|}{ Opportunities and threats } \\
\hline \multirow{4}{*}{$\begin{array}{c}\text { Financial } \\
\text { factors }\end{array}$} & general financial and economic potential of the company \\
\cline { 2 - 3 } & product cost \\
\cline { 2 - 3 } Process and & profit (loss) of the enterprise \\
\cline { 2 - 2 } technological & financial stability \\
\cline { 2 - 2 } & enterprise availability with the basic means of production \\
\cline { 2 - 3 } & behavior of the productivity growth curve \\
\cline { 2 - 2 } & serfection of production technologies \\
\cline { 2 - 2 } & qualified service of the technological equipment \\
\cline { 2 - 2 } & violation of technological process \\
\hline \multirow{5}{*}{ Marketing } & level of goods competitiveness \\
\cline { 2 - 2 } & breadth of the product range \\
\cline { 2 - 2 } & production quality \\
\cline { 2 - 2 } & effectiveness of pricing policy \\
\cline { 2 - 2 } & quality of customer service \\
\hline
\end{tabular}

The social factors affecting the enterprise security should be identified as follows (table 3).

Environmental factors include: the impact of natural and man-made factors on the economic activity of the enterprise (floods, earthquakes, tornadoes, landslides, avalanches, epidemics).

Identification and elimination of economic, social and environmental factors in a certain period of time will allow to increase the level of safety at the enterprise and to improve the course of the production process, which ensures maximum economic effect for a given economic unit in a certain branch of economy.

Identification and elimination of economic, social and environmental factors will allow to increase the level of enterprise security and to improve the progress of production process, which ensures maximum economic effect for a given economic unit in a certain branch of economy. 
Table 3

Classification of social factors

\begin{tabular}{|c|l|}
\hline Social factors & \multicolumn{1}{|c|}{ Opportunities and threats } \\
\hline \multirow{4}{*}{$\begin{array}{c}\text { Organizational } \\
\text { and management }\end{array}$} & $\begin{array}{l}\text { compliance of the organizational structure with } \\
\text { the enterprise needs }\end{array}$ \\
\cline { 2 - 2 } & level of managers competence \\
\cline { 2 - 2 } & management efficiency \\
\hline \multirow{4}{*}{ Human } & level of personnel professional training \\
\cline { 2 - 2 } & $\begin{array}{l}\text { opportunity for career advancement } \\
\text { providing conditions for the realization of labor } \\
\text { potential } \\
\text { satisfaction of employees' needs }\end{array}$ \\
\cline { 2 - 2 } & $\begin{array}{l}\text { normal working conditions of workers in } \\
\text { production shops and workplaces }\end{array}$ \\
\hline
\end{tabular}

The purpose of ensuring the enterprise security should be a comprehensive counteraction to potential and real threats, the elimination or minimization of which should guarantee the entity the success of operation in unstable conditions of the external and internal environment.

As pointed out above, for the normal operation of the enterprise it is necessary to be able to counteract threats. These threats can come from different ways and the main ones are selected in groups and defined as types of security.

Among the list of types of enterprise security, precious little attention is paid in literature to such an important type of security as process safety. Its main point, basis, organization, formation and action of the concept are not described. Therefore, it is necessary to define and analyze the process safety of the enterprise and to find its connection with other types of security.

Therefore, process safety is a state of the enterprise that ensures the normal functioning of production processes and the ability to counteract the impacts of negative threats that cause production failure. A production failure is an event that involves the loss of an object's ability to carry on the required function, that is, a disturbance of the capable state of the object. If we consider the relationship of process safety with other types of security, it must be said that process safety directly contributes to the economic 
effect of the operating activities of the enterprise, and as a result generates a net cash flow. In case of negative situations related to the business processes, the further functioning and implementation of measures for other types of security loses any substance, as all units that try to maintain economic, financial and other types of security without the normal course of the manufacturing cycle are inappropriate.

Disturbance of the normal operation can be influenced by external and / or internal factors. Regardless of these factors, the enterprise's reserves are an important lever of influence on the process safety.

The reserve is a part of the production potential, which is not used in normal conditions for the enterprise. The reserve is estimated as the difference between the maximum capabilities (capacity) of the process under favorable conditions and its actual use. In order to ensure the stability of the enterprise, it is necessary to identify and use reserves of production potential.

Production stocks are raw materials, materials, semi-finished products, unfinished goods and products for industrial purposes, which are at different stages of production, spare parts and other goods suitable for industrial consumption.

There are two main groups of these reserves: enterprise production potential reserves and management potential reserves. The structure of reserves that affect the process safety of the enterprise is shown in Fig. 3.

Depending on the processes that take place in the enterprise and affect the efficiency of its activities, they can be structured as follows:

- production potential - characterized by the maximum volume of products (services) that can produce an enterprise in favorable conditions;

- management potential - characterized by the maximum amount of management information that can be processed by a management body, which is necessary for the smooth and efficient operation of the management object.

It is the production potential reserves that can increase process safety and neutralize any factors that negatively affect the operation of the enterprise. One of the purposes of enterprise safety management is to identify and increase the capacity of the enterprise and its reserves.

Therefore, the larger the reserves are, the greater abilities to influence process safety the enterprise has. 


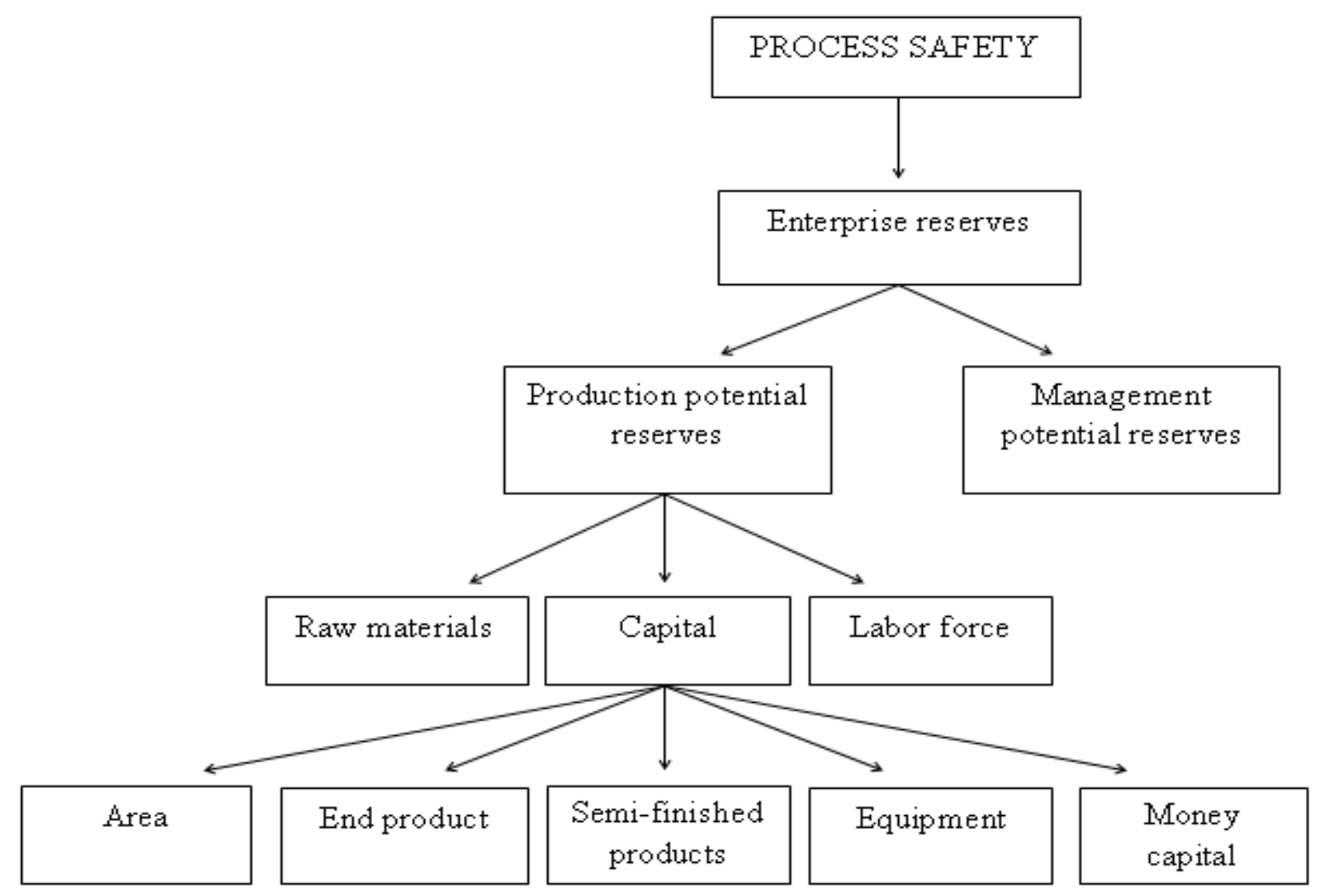

Figure 3. Factors of influence on process safety

In terms of enterprise security, it is advisable to increase capacity reserves. But the increase in these reserves is associated with additional costs, freezing of capital. On this point, the company is interested in creating minimum capacity reserve. The existing contradictory tendency in the management of productive capacity reserve leads to the need to formulate and solve an optimization problem to find such a level of production capacity at which the total costs of freezing idle (reserve) capacity and losses of the company from stoppage associated with the impact of various negatively directed at the enterprise factors will be minimal.

The method of searching for production reserves should be considered as part of a dynamic system that must be created at the enterprise to receive information about additional capabilities of the enterprise and its business units.

It is possible to influence process safety performance by changing these factors. Improving security can be ensured by the mentioned factors.

Increasing the enterprise capacity, production, stocks of raw materials and semi-finished products can increase the level of security. Due to this, the company requires some additional costs. 
The nature of this reliance is shown in Fig. 4.

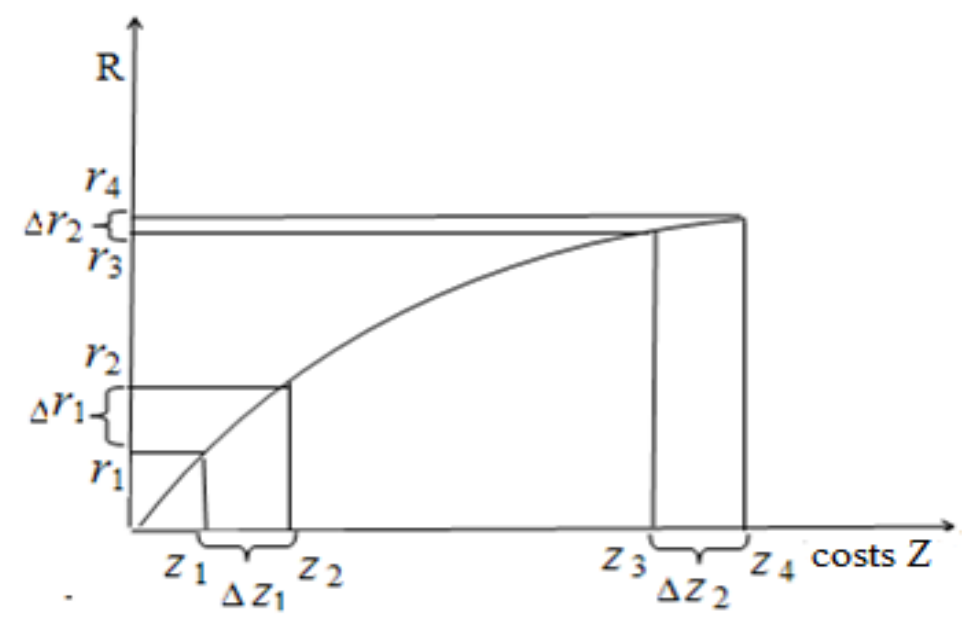

Figure 4. Reliance of the level of process safety on the costs for increasing production factors

Let us set:

$\mathrm{R}$ - level of process safety;

$\mathrm{Z}$ - costs for increasing the factors that affect security level.

The peculiarity of this reliance is its nonlinear nature, that is, the necessary costs for increasing security rise as it increases. As costs rise from the level z1 to $\mathrm{z} 2$, that is, by the value of $\Delta z_{1}(\mathrm{z} 2-\mathrm{z} 1)$, the security level increases by the value of $\Delta r_{1}(\mathrm{r} 2-\mathrm{r} 1)$. If process safety rises to the level of r3, such growth is associated with an increase in costs. Suppose that the security level is equal to $R=r 3$, and the increase in the cost of production factors by the same amount, that is, from $\mathrm{z} 3$ to $\mathrm{z} 4$ $\left(\Delta z_{2}=z_{4}-z_{3}=\Delta z_{1}\right)$, will increase the security level from the level of $\mathrm{R}=\mathrm{r} 3$ to the level of $\mathrm{R}=\mathrm{r} 4$, that is $\Delta r_{2}$, which is much smaller than $\Delta r_{1}$.

The analysis of the above reliance leads to the conclusion that increasing the level of security by the same amount is associated with different specific costs of production factors (Fig. 5).

So increasing the level from $\mathrm{r} 1$ to $\mathrm{r} 2$ by the value of $\Delta r_{1}$ requires additional costs $\Delta z_{1}\left(\Delta z_{1}=z_{2}-z_{1}\right)$. Increasing the security level by the same value of $\Delta r_{2}=\Delta r_{1}$ from the level $r_{3}$ to $r_{4}$ requires $\Delta z_{2}$ cost which is much higher than the cost of $\Delta z_{1}$. 


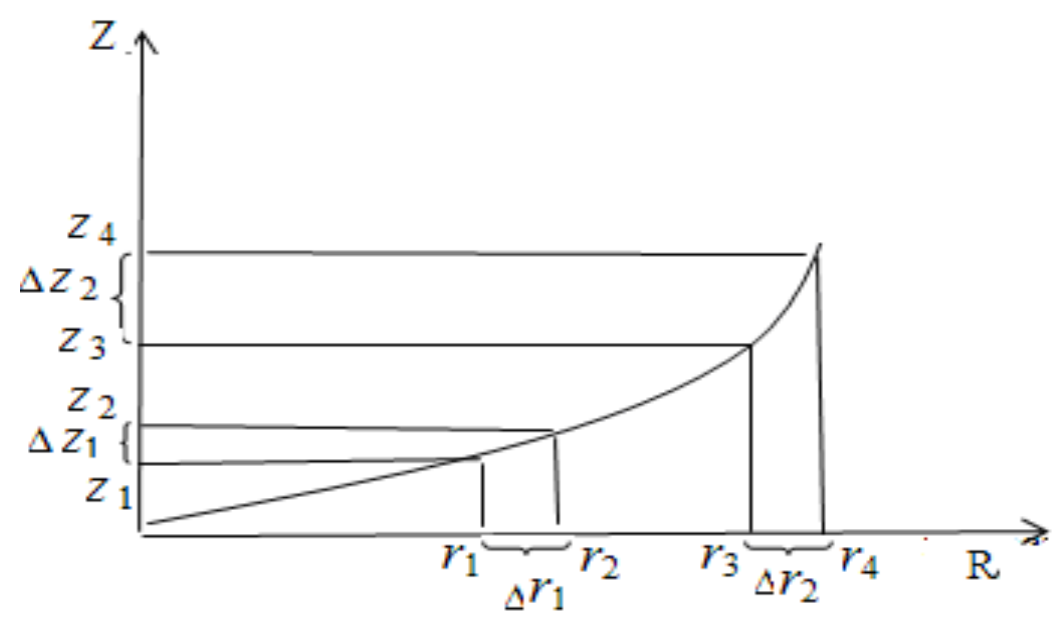

\section{Figure 5. Reliance of the amount of costs for increasing production factors on the level of process safety}

The above features of the reliance of process safety on production factors and the cost of their implementation makes it advisable to determine optimal level of process safety rather than considering the problem of improving its level.

Process safety of the enterprise depends to a great extent on such properties of the system as risk and reliability of production processes.

According to ${ }^{7}$ at risk we will understand the feature of the system under the influence of external and / or internal factors to change from a state of normal functioning (performance capability) to a state of failure. In this case, the reliability of the system can be taken as a feature of the system to maintain a state of normal functioning (performance). Functioning state is the state in which the system enforces specified functions (goal achievement).

The level of reliability can be measured by the probability of maintaining the functioning state.

According to ${ }^{7}$ lets determine the reliability of the system at a finite time interval $(0, \mathrm{~L})$. During this time, the system may be in working E1 or non-working E0 states.

Determination of the system reliability assessment over a period of time $(0, \mathrm{~L})$ :

$$
H(1, L)=\frac{r \times m}{L}
$$

where $\mathrm{r}-$ the number of cases when the system is in working order;

${ }^{7}$ Клименюк М.М., Брижань I.А. Управління ризиками в економіці : навчальний посібник. Київ : Просвіт, 2000. 256 с. 
$\mathrm{m}$ - the average duration of the system in working condition, days;

$\mathrm{L}$ - the time interval during which the study took place, days.

The reliability of the system depends on a large number of production factors, among which is the reserve of productive capacity reserve.

Here is an example of the impact of the productive capacity reserve on the system reliability. We provide the initial data in the form of table 4 .

Let us set:

$\mathrm{H}$ - level of reliability;

$\Delta \mathrm{N}$ - productive capacity reserves.

Table 4

Data on the reliance of reliability on productive capacity reserves

\begin{tabular}{|c|c|c|}
\hline № & $\Delta \mathrm{N} \%$ & $\mathrm{H}$ \\
\hline 1 & 2 & 0,25 \\
\hline 2 & 5 & 0,43 \\
\hline 3 & 10 & 0,6 \\
\hline 4 & 20 & 0,76 \\
\hline 5 & 30 & 0,85 \\
\hline 6 & 40 & 0,9 \\
\hline 7 & 50 & 0,92 \\
\hline
\end{tabular}

The graph is based on the data (Fig. 6).

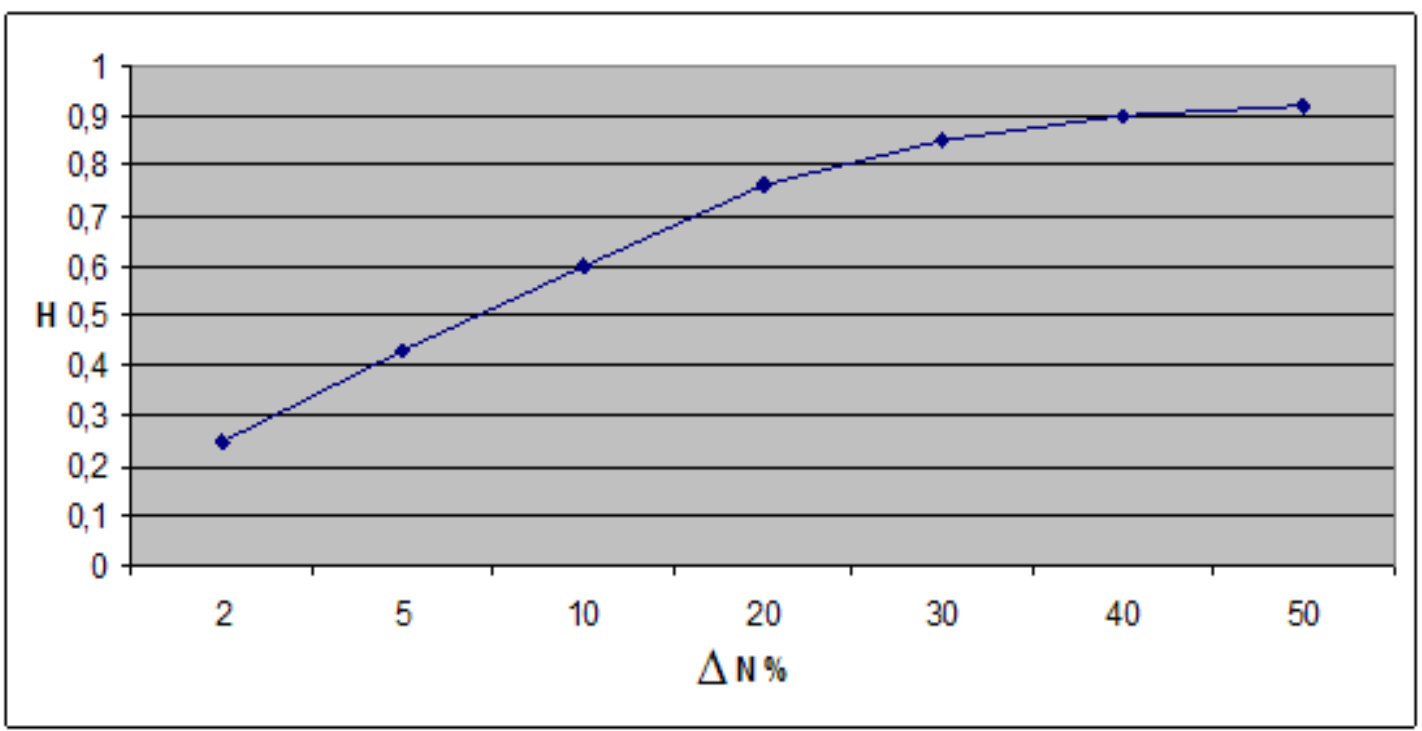

Figure 6. Reliance of reliability on productive capacity reserves 


\section{CONCLUSIONS}

In order to determine the optimum level of reliability, it is necessary to build, in addition to certain reliance of reliability on productive capacity reserves, a function of costs and losses associated with insufficient reliability of production processes. The nature of these reliance is shown in Fig. 7.

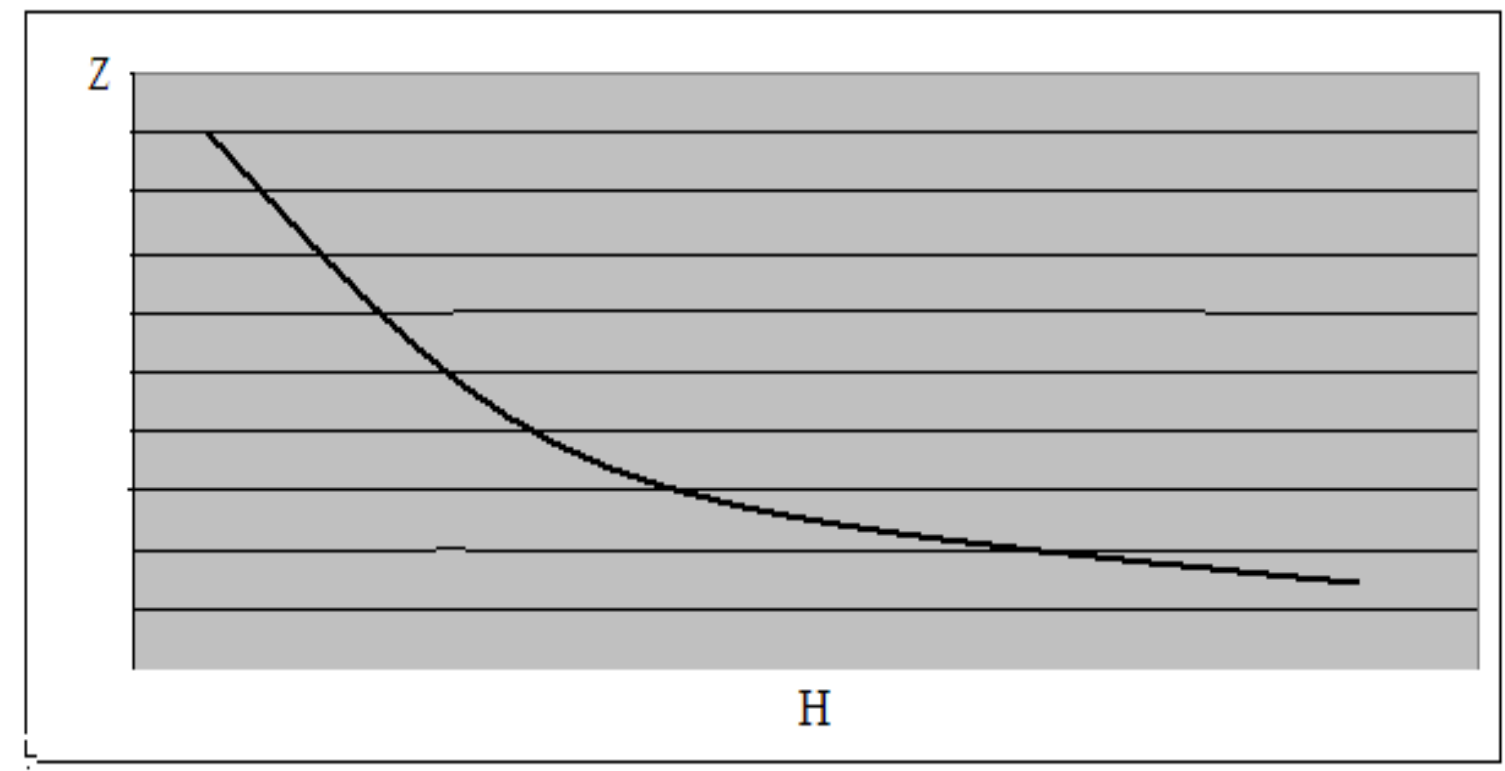

\section{Figure 7. Reliance of costs and losses of the enterprise, connected with stoppage of production processes, on the level of reliability}

\section{SUMMARY}

Therefore, the production reliability and the process safety are related to the costs and losses of the enterprise, which have opposite tendencies. On the one hand, improving the production reliability by reserving production capacity entails additional costs. On the other hand, increasing reliability leads to reduced production stoppage and consequently a reduction in costs and losses.

Taking into account two trends allows us to form the concept of determining the optimal level of security. The joint consideration and resolution of the costs reliance function on reserving and increased reliability, as well as the costs and losses of system failures from insufficient reliability, are the basis for determining such a level of enterprise process safety, with which these total costs will be minimal. 


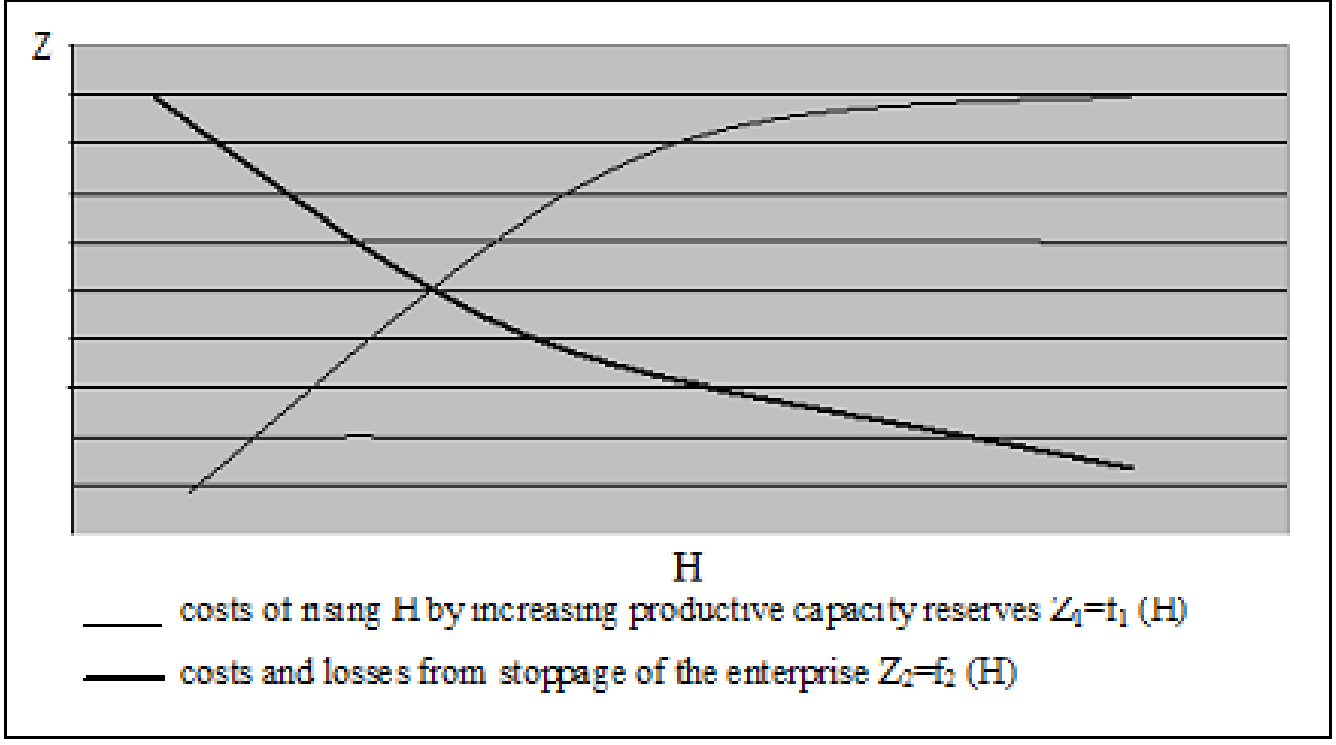

\section{Figure 8. Reliance of costs and losses of the enterprise on the level of reliability}

The dependence of costs on the level of reliability is the basis for constructing the objective function on min total costs for the production conditions of a particular enterprise.

\section{REFERENCES}

1. Користін О.С., Чернявський С.С. Протидія відмиванню коштів в Україні: правові та організаційні засади правоохоронної діяльності : навчальний посібник. Київ, 2009. 612 с.

2. Ігнашкіна Т.Б. Економічна безпека підприємства та іiі трактування у праць. ПДТУ. Маріуполь, 2011. Т. 2. С. 204-207.

3. Фінанси : Підручник. 4-те вид. Київ : Центр учбової літератури, 2009. 312 c.

4. Швець Н.Р. Методи виявлення і збереження кадрової безпеки, або Як перемогти зловживання персоналу. Київ : Журнал «Персонал». 2006. № 5.

5. Іванілов О.С. Економіка підприємства : підручник 2-ге видання Затверджено Міністерством освіти і науки України для студентів вищих навчальних закладів. Київ : «Центр учбової літератури», 2011. 
6. Ортинський В.Л., Керницький І.С., Живко З.Б. Економічна безпека підприємств, організацій та установ : навчальний посібник. Київ : Правова єдність, 2009. 542 с.

7. Клименюк М.М., Брижань І.А. Управління ризиками в економіці : навчальний посібник. Київ : Просвіт, 2000. 256 с.

Information about the author:

Demenska K. S.

Lecturer, Department of Management and International Economic Relations, V. I. Vernadsky Taurida National University 33, John McCain str., Kyiv, 02000, Ukraine 